\title{
Chemical changes in the spinal cord in Friedreich's ataxia and motor neurone disease
}

\author{
N. ROBINSON \\ From the Department of Chemical Pathology, Institute of Neurology, \\ The National Hospital, Queen Square, London
}

This communication reports a comparison of the chemical constitution of affected and unaffected regions of white matter in the spinal cords of Friedreich's ataxia and motor neurone disease (MND). Friedreich's ataxia is a member of the heredo-familial spino-cerebellar diseases, the mode of inheritance being mainly recessive. Most cases of MND in Europe have no family history (Spillane, 1962) and the duration of the disease is shorter than Friedreich's ataxia. Little is known of the aetiology of the diseases, but in both conditions specific tracts of the spinal cord are involved.

Recent enzyme studies on Friedreich's ataxia suggested that an alteration in carbohydrate metabolism involving the direct oxidation pathway and also a change in the regulation of phosphate were taking place in the spinal cord (Robinson, $1966 \mathrm{a}, \mathrm{b})$. In a study of five cases of MND, alterations in oxidative enzyme and phosphatase activities were demonstrated in glia cells of the spinal cord white matter (Robinson, 1966c). In this study the breakdown in metabolism within affected tracts of the spinal cord has been further investigated. Dissection of the affected and unaffected areas of the spinal cords and examination of the chemical composition and integrity of the molecular complexes involved have suggested further changes in the degenerative processes taking place in these regions.

\section{MATERIALS}

Spinal cord was obtained at necropsy from seven pathological cases and four controls. Patients with Friedreich's ataxia, durations of the disease, storage before necropsy (in parentheses) and regions of the cord analysed were: Case 1 , male age 30 years, duration 13 years, (14 hr) thoracic cord; Case 2, male age 24 years, duration 11 years, (6 hr) thoracic and lumbar cord; Case 3, female age 67 years, duration 32 years, $(16 \mathrm{hr})$ thoracic cord. The patients with MND were: Case 4, male age 21 years, duration 13 months, $(9 \mathrm{hr})$ cervical cord; Case 5, female age 56 years, duration 22 months, (11 hr) lumbar cord; Case 6, female age 54 years, duration
22 months, $(9 \mathrm{hr})$ lumbar cord; Case 7, male age 62 years, duration 24 months, $(13 \mathrm{hr})$ lumbar cord. Control spinal cord was from five cases having no evidence of neuropathological involvement of the brain-stem and cord. Differences between control and pathological material due to post-mortem changes were minimized by using controls of similar ages and subjected to the same conditions at necropsy. Material was rapidly frozen, stored at $-25^{\circ}$ for the minimum of time to reduce enzymatic action, and analysed.

\section{METHODS}

Cylinders of white matter of the spinal cord were removed with a thin-walled capillary tube at $12^{\circ}$ from affected posterior and lateral tracts, and also from the unaffected anterior regions of Friedreich's ataxia cases. Cylinders of tissue were removed from the affected laterab tracts and unaffected anterior and posterior areas of the MND cases. The same regions were removed from normal spinal cord. Weighed portions of dissected tissue were dried to constant weight in a vacuum dessicator for dry weights and the remaining fresh tissue treated for extraction of cholesterol (free and esterified), phospholipids, proteolipids, chloroform-methanolinsoluble proteins, and free amino acids.

EXTRACTION PROCEDURES Chloroform, phospholipids, and proteolipids were extracted according to Folch, Lees, and Sloane-Stanley (1957). Cholesterol (free and esterified) was estimated by the method of Sperry and Webb (1950) and the four phospholipids, separated by thin layer chromatography, were estimated for phosphorus content according to Bartlett (1959). Proteolipids in the lower organic phase of the partitioned chloroformmethanol extract were purified as described by Lees, Carr, and Folch (1964), deproteinized with $10 \%$ TCA the protein material washed successively with $95 \%$ ethanol and chloroform-methanol $(2: 1 \mathrm{v} / \mathrm{v})$, dried with ether, and the amino acid content estimated as described elsewhere (Robinson and Williams, 1965). Soluble proteins in the upper aqueous phase of the partitioned chloroform-methanol extract were deproteinized with $10 \%$ TCA, washed, dried, and analysed for amino acid content as for proteolipid-protein. Free amino acids were extracted and estimated quantitatively as previously described (Robinson and Williams, 1965). Three 330 
separate preparations, analysed in triplicate, were conducted on normal and pathological material.

\section{RESULTS}

The spinal cord white matter mean values of total and free cholesterol, phospholipids, proteolipidproteins, insoluble and soluble proteins, and free amino acid profiles for the five controls and pathological tissue are shown in Tables I, II and III.

A comparison of control results with other investigations on normal white matter show that cholesterol was lower than reported by Brante (1949) but in general agreement with Davison and Wajda (1962), Soto, De Bohner, and Del Carmen Calviño (1966), and Prensky and Moser (1966). The control spinal cord phospholipids were in general agreement with Soto et al. (1966), but higher than in cerebral white matter reported by Prensky and Moser (1966) and Balakrishnan, Goodwin, and Cumings (1961). The mean values for control proteolipid proteins were in agreement with Hess and Lewin (1965) but lower than the values of Prensky and Moser (1966) on infant brain, but for chloroform-methanol-insoluble proteins the mean values were in the lower range reported by Hess and Lewin (1965). No independent figures are available for free amino acids in spinal cord (Table III).
In two of three Friedreich's ataxia cases cholesterol levels in the lateral corticospinal and posterior tracts were low and all three showed minor esterified cholesterol; the levels in MND tissue were normal (Table I).

Total phospholipid-phosphorus content in the affected posterior tracts of two Friedreich's ataxia cases showed differences from the control levels but no one phospholipid was significantly raised. The total phospholipid in all MND cases appeared normal.

Two of three Friedreich's ataxia cases exhibited low proteolipid-protein and high insoluble protein levels but with acceptable total protein levels; in one of these cases 'soluble' protein was above the normal amount partitioned. The Friedreich's ataxia Case 3 exhibited a high 'insoluble' protein level. The MND cases exhibited the same pattern of proteolipidprotein and 'insoluble' protein levels as the two Friedreich's ataxia cases, while the other cases showed loss of proteolipid-protein only. The amino acid profile of the protein hydrolysates indicated that the proteolipid-protein lost from the affected tracts did not involve protein with specifically high acidic or basic amino acid constituents.

The free amino acid content of the spinal cords in Friedreich's ataxia showed low levels of aspartic and glutamic acids in three cases, and leucine and glutamine in two; in MND glutamine, aspartic and

T A B L E I

CHOLESTEROL AND PHOSPHOLIPID LEVELS IN SPINAL CORDS OF CONTROLS, FRIEDREICH'S ATAXIA, AND MND (UNITS: CHOLESTEROL AND TOTAL PHOSPHOLIPID-PHOSPHORUS IN MG/G DRY WT)

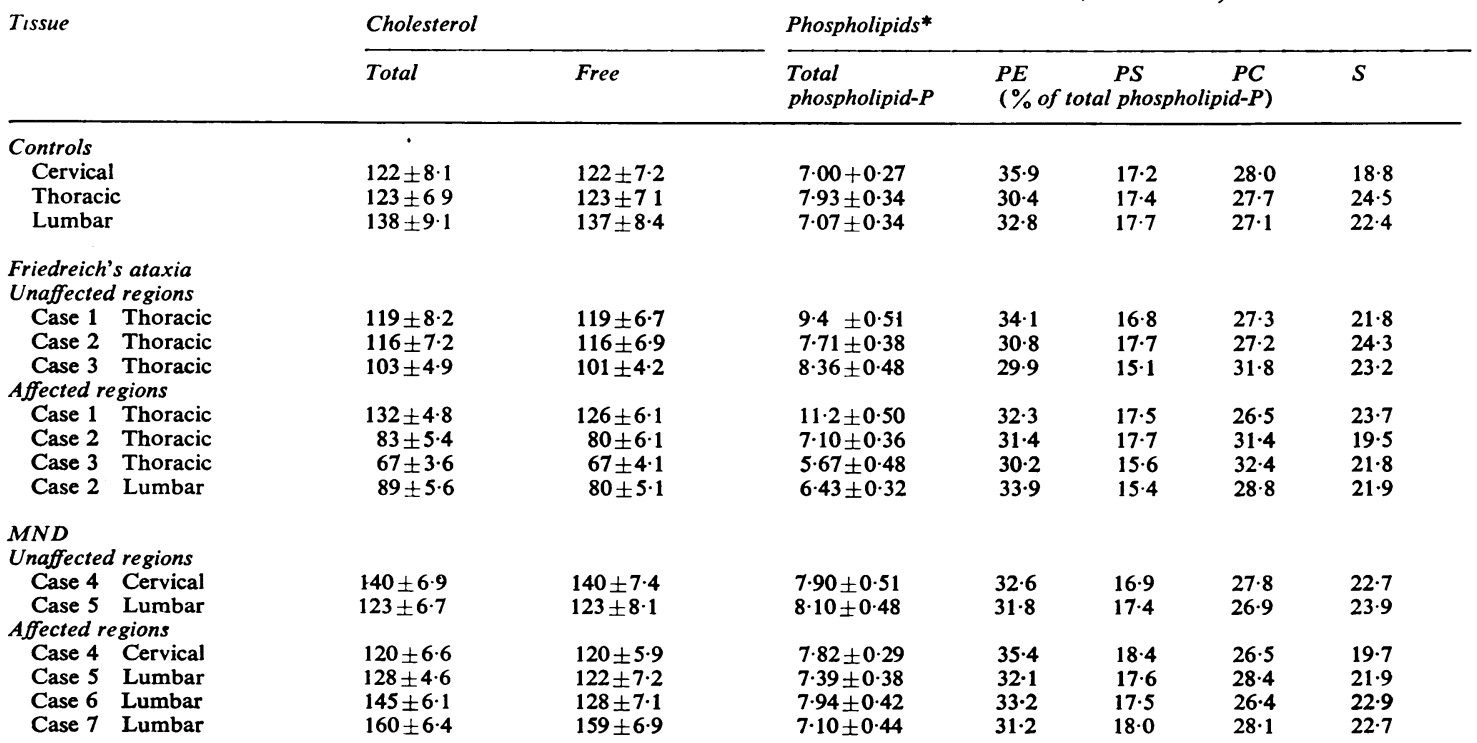

*PE $=$ phosphatidylethanolamine, $\mathrm{PS}=$ phosphatidylserine, $\mathrm{PC}=$ phosphatidylcholine, $\mathrm{S}=$ sphingomyelin 
glutamic acids were low in two cases. In both conditions some other amino acids were at borderline levels.

\section{DISCUSSION}

This investigation was undertaken to examine the chemical composition of normal tracts and tracts showing loss of myelin in the spinal cords of two clinically well-characterized neurological disorders with the possibility that chemical changes may indicate an alternation in a metabolic pathway within the affected tracts.

\section{TABLE II}

PROTEIN LEVELS IN SPINAL CORDS OF CONTROLS, FRIEDREICH'S ATAXIA, AND MND (UNITS: MG/G DRY WT) Tissue

\begin{tabular}{|c|c|c|c|}
\hline & $\begin{array}{l}\text { Proteolipid } \\
\text { protein }\end{array}$ & $\begin{array}{l}\text { Insoluble } \\
\text { protein }\end{array}$ & $\begin{array}{l}\text { Soluble } \\
\text { protein }\end{array}$ \\
\hline \multicolumn{4}{|l|}{ Controls } \\
\hline $\begin{array}{l}\text { Cervical } \\
\text { Thoracic } \\
\text { Lumbar }\end{array}$ & $\begin{array}{l}46 \cdot 5 \pm 3 \cdot 6 \\
52 \cdot 4 \pm 3 \cdot 8 \\
49 \cdot 3 \pm 3 \cdot 0\end{array}$ & $\begin{array}{l}237 \cdot 5 \pm 18 \\
245 \cdot 1 \pm 20 \\
246 \cdot 5 \pm 19\end{array}$ & $\begin{array}{l}1 \cdot 2 \pm 0 \cdot 6 \\
3 \cdot 8 \pm 0 \cdot 6 \\
6 \cdot 6+2 \cdot 9\end{array}$ \\
\hline \multicolumn{4}{|l|}{$\begin{array}{l}\text { Friedreich's ataxia } \\
\text { Unaffected regions }\end{array}$} \\
\hline $\begin{array}{l}\text { Case } 1 \text { Thoracic } \\
\text { Case } 2 \text { Thoracic } \\
\text { Case } 3 \text { Thoracic } \\
\text { Affected regions }\end{array}$ & $\begin{array}{l}52 \cdot 7 \pm 4 \cdot 6 \\
67 \cdot 8 \pm 2 \cdot 8 \\
35 \cdot 1 \pm 4 \cdot 9\end{array}$ & $\begin{array}{l}339 \cdot 0 \pm 29 \\
237 \cdot 0 \pm 20 \\
281 \cdot 9 \pm 21\end{array}$ & $\begin{array}{l}2 \cdot 8 \pm 0.9 \\
1 \cdot 9 \pm 0 \cdot 9 \\
3 \cdot 2 \pm 1 \cdot 1\end{array}$ \\
\hline $\begin{array}{ll}\text { Case } 1 & \text { Thoracic } \\
\text { Case } 2 & \text { Thoracic } \\
\text { Case } 3 & \text { Thoracic } \\
\text { Case } 2 & \text { Lumbar } \\
\text { MND } & \end{array}$ & $\begin{array}{r}63.2 \pm 5.8 \\
41.4 \pm 4.9 \\
9.75 \pm 2.9 \\
31.8 \pm 5.0\end{array}$ & $\begin{array}{l}483 \cdot 5 \pm 51 \\
338 \cdot 0 \pm 35 \\
462 \cdot 0 \pm 43 \\
291 \cdot 0 \pm 31\end{array}$ & $\begin{array}{r}1 \cdot 9 \pm 1 \cdot 0 \\
11 \cdot 5 \pm 3 \cdot 1 \\
2 \cdot 9 \pm 0.9 \\
2 \cdot 1 \pm 1 \cdot 1\end{array}$ \\
\hline $\begin{array}{l}\text { Unaffected regions } \\
\text { Case } 4 \text { Cervical } \\
\text { Case } 5 \text { Lumbar } \\
\text { Affected regions }\end{array}$ & $\begin{array}{l}51 \cdot 4 \pm 5 \cdot 1 \\
55 \cdot 7 \pm 4.9\end{array}$ & $\begin{array}{l}289 \cdot 0 \pm 18 \\
296 \cdot 0 \pm 22\end{array}$ & $\begin{array}{l}1.7 \pm 0.4 \\
3.4 \pm 1.4\end{array}$ \\
\hline $\begin{array}{l}\text { Case } 4 \text { Cervical } \\
\text { Case } 5 \text { Lumbar } \\
\text { Case } 7 \text { Lumbar }\end{array}$ & $\begin{array}{l}34 \cdot 0 \pm 4 \cdot 1 \\
26 \cdot 5 \pm 3 \cdot 4 \\
28 \cdot 5 \pm 3 \cdot 4\end{array}$ & $\begin{array}{l}298 \cdot 4 \pm 21 \\
311 \cdot 2 \pm 36 \\
218 \cdot 1 \pm 34\end{array}$ & $\begin{array}{l}3 \cdot 5 \pm 1 \cdot 6 \\
6 \cdot 0 \pm 3 \cdot 0 \\
2 \cdot 5 \pm 0 \cdot 7\end{array}$ \\
\hline
\end{tabular}

Changes in chemical composition of the affected tracts in Friedreich's ataxia and MND suggested that they were probably secondary processes and not primary biochemical defects since the changes were common to both conditions, which have different genetic aspects and exhibit different clinical and pathological features, although the lateral corticospinal tract investigated in this study was commonly affected.

The lipid profile of the affected regions of white matter compared with unaffected regions and the same tracts in the controls showed no significant differences in the relative amounts of each component of the myelin, except the loss of lipid which is in conjugation with protein as proteolipid, the protein component appearing in the chloroformmethanol-insoluble protein fraction. It is possible that the proteolipid content may have been reduceda substantial reduction of white matter proteolipids has been reported in a maple syrup urine case (Prensky and Moser, 1966) -and the protein moiety estimated in the extracts was being reinforced by protein derived from proliferating glia cells or swollen astrocytes and macrophages which are known to have high protein contents (Dixon, 1954 Rubinstein and Smith, 1962). However, the insolubli protein levels were normal and it is fortuitous if reduced lipoprotein-protein was being so closelgcompensated by protein from gliosis. It is feasible that a hydrolytic reaction due to factors yet unknowb but which may include poor arterial supply o $\frac{\rho}{9}$ the abnormally high astrocytic enzyme activit $\overrightarrow{0}$ (Robinson, 1966a, b, c) may have been producing dissociation of the lipid-protein complex in affected tracts.

The spinal cord free amino acids in Friedreich's ataxia and MND showed abnormally low levels of

T A B L E I I I

FREE AMINO ACIDS ( $\mu$-MOLE/G DRY WT TISSUE) IN SPINAL CORDS OF CONTROLS AND AFFECTED REGIONS OF FRIEDREICH'S ATAXIA AND MND CASES

\begin{tabular}{|c|c|c|c|c|c|c|c|c|c|}
\hline \multirow[b]{2}{*}{ Amino acid } & \multicolumn{2}{|c|}{ Controls } & \multicolumn{3}{|c|}{ Friedreich's ataxia } & \multicolumn{4}{|c|}{ Motor neurone disease } \\
\hline & Mean & Range & Case 1 & Case 2 & Case 3 & Case 4 & Case 5 & Case 6 & Case 7 \\
\hline $\begin{array}{l}\text { Alanine } \\
\text { Arginine } \\
\text { Aspartic acid } \\
\text { Cystathionine } \\
\text { Cysteic acid } \\
\text { Glutamic acid } \\
\text { Glutamine } \\
\text { Glycine } \\
\text { Histidine + lysine } \\
\text { Leucine + isoleucine } \\
\text { Serine } \\
\text { Taurine } \\
\text { Threonine } \\
\text { Tyrosine } \\
\text { Valine + methionine }\end{array}$ & $\begin{array}{c}14 \cdot 4 \\
2 \cdot 26 \\
6 \cdot 03 \\
5 \cdot 14 \\
1 \cdot 20 \\
18 \cdot 9 \\
14 \cdot 3 \\
5 \cdot 98 \\
5 \cdot 09 \\
7 \cdot 38 \\
7 \cdot 67 \\
3 \cdot 40 \\
4 \cdot 20 \\
2 \cdot 50 \\
4 \cdot 27\end{array}$ & $\begin{array}{c}8.91-19.9 \\
1.97-2.55 \\
4.60-7.46 \\
3.40-6.88 \\
17-1-20.7 \\
11.9-16.7 \\
4.63-9.33 \\
4.06-6.12 \\
5.56-9.20 \\
5.35-9.99 \\
2.40-4.40 \\
3.15-5.25 \\
1.56-3.44 \\
2.80-5.74\end{array}$ & $\begin{array}{c}13 \cdot 2 \\
2.94 \\
2 \cdot 27 \\
10 \cdot 0 \\
-10 \cdot 5 \\
15 \cdot 4 \\
8 \cdot 86 \\
4 \cdot 24 \\
0.94 \\
8 \cdot 61 \\
2 \cdot 65 \\
4 \cdot 88 \\
2 \cdot 79 \\
5 \cdot 62\end{array}$ & $\begin{array}{l}16 \cdot 3 \\
2 \cdot 01 \\
2 \cdot 22 \\
6 \cdot 16 \\
1 \cdot 0 \\
9 \cdot 70 \\
8 \cdot 8 \\
4 \cdot 90 \\
3 \cdot 99 \\
2 \cdot 90 \\
7 \cdot 28 \\
3 \cdot 05 \\
3 \cdot 00 \\
1 \cdot 48 \\
4 \cdot 81\end{array}$ & $\begin{array}{c}15 \cdot 6 \\
1 \cdot 89 \\
3 \cdot 10 \\
5 \cdot 82 \\
10 \cdot 4 \\
7 \cdot 61 \\
8 \cdot 90 \\
4 \cdot 62 \\
5 \cdot 10 \\
7 \cdot 74 \\
2 \cdot 98 \\
5 \cdot 14 \\
2 \cdot 62 \\
3 \cdot 80\end{array}$ & $\begin{array}{r}14 \cdot 9 \\
2 \cdot 14 \\
2 \cdot 78 \\
4 \cdot 13 \\
0 \cdot 98 \\
9 \cdot 31 \\
16 \cdot 62 \\
7 \cdot 30 \\
5 \cdot 14 \\
6 \cdot 21 \\
8 \cdot 98 \\
2 \cdot 10 \\
4 \cdot 62 \\
3 \cdot 52 \\
5 \cdot 54\end{array}$ & $\begin{array}{l}8 \cdot 80 \\
1 \cdot 69 \\
1 \cdot 52 \\
4 \cdot 13 \\
-1 \\
9 \cdot 11 \\
4 \cdot 61 \\
6 \cdot 72 \\
4 \cdot 01 \\
5 \cdot 30 \\
6 \cdot 25 \\
2 \cdot 54 \\
5 \cdot 24 \\
3 \cdot 41 \\
4 \cdot 17\end{array}$ & $\begin{array}{c}17 \cdot 7 \\
2.42 \\
4 \cdot 80 \\
3.94 \\
18 \cdot 3 \\
10 \cdot 5 \\
8 \cdot 33 \\
3.89 \\
6.91 \\
7 \cdot 18 \\
3.01 \\
3.52 \\
2.20 \\
3.94\end{array}$ & $\begin{array}{c}9.06 \\
1.88 \\
4.40 \\
7 \cdot 11 \\
-15.3 \\
8.42 \\
4.52 \\
3.98 \\
5.38 \\
5.10 \\
1.96 \\
2.98 \\
1.45 \\
2.72\end{array}$ \\
\hline
\end{tabular}


two amino acids (aspartic and glutamic) that play a central role in brain metabolism; another amino acid, leucine, was low in Friedreich's ataxia. Factors governing a raised cystathionine cannot be explained, however; a pyridoxine deficiency can cause its accumulation in the brain (Tallon, 1962) but no evidence of such a deficiency has been reported in the two pathological conditions. Alterations in the profile of free amino acids in these disorders may be due to two factors: (1) artificially raised amino acids are known to restrict the passage of some other amino acids into the brain; (2) the amino acid abnormalities may have resulted from changes in composition of the blood at the terminal stages, which in turn produced alterations in amino acid flux and the exchange rates between protein uptake and the amino acid pool (Lajtha, 1964). The differences were, however, dissimilar in character and magnitude to those in necropsy brains of infants with maple syrup disease.

\section{SUMMARY}

The lipid, proteolipid, protein, and amino acid composition of affected regions of white matter in the spinal cords of cases of Friedreich's ataxia and motor neurone disease are compared with adjacent unaffected regions and normal spinal cord.

Two changes seen were (1) the affected regions in both diseases showed lipid lost from proteolipids, the protein residue retained as insoluble protein; (2) the free amino acid content in affected tracts of the spinal cords in both conditions showed changes in glutamine, aspartic and glutamic acids. Possible factors in the metabolism of the spinal cord effecting these changes are discussed.

The author thanks Professor J. N. Cumings for his continued interest in the project and the Evelyn Staines Fund for financial support. The author also thanks Dr. R. L. Hewer, The Churchill Hospital, for the Friedreich's ataxia Case 1; Dr. V. Kendall, Royal Hospital and Home for Incurables, for Case 2: Dr. Q. J. G. Hobson, West Middlesex Hospital, for
Case 3; Dr. B. M. Phillips, neurologist, for the MND Cases 1, and 2; Professor R. W. Gilliatt, Department of Neurology, for Case 3; Dr. C. P. Silver, St. Matthew's Hospital, for Case 4, and Professor W. Blackwood, Department of Neuropathology, for the controls.

\section{REFERENCES}

Balakrishnan, S., Goodwin, H., and Cumings, J. N. (1961). The distribution of phosphorus containing lipid compounds in the human brain. J. Neurochem., 8, 276-284.

Bartlett, G. R. (1959). Phosphorus assay in column chromatography. J. biol. Chem., 234, 466-468.

Brante, G. (1949). Studies on lipids in nervous system with special reference to quantitative chemical determination and topical distribution. Acta physiol. Scand., Suppl. 63, 18, 1-189.

Davison, A. N., and Wajda, M. (1962). Analysis of lipids from fresh and preserved adult human brains. Biochem. J., 82, 113-117.

Dixon, K. C. (1954). Cytochemistry of a cerebral scar. J. Path. Bact., 68, 85-88.

Folch, J., Lees, M., and Sloane-Stanley, G. H. (1957). A simple method for the isolation and purification of total lipids from animal tissue. J. biol. Chem., 226, 497-509.

Hess, H. H., and Lewin, E. (1965). Microassay of biochemical structural components in nervous tissue. II. Methods of cerebrosides, proteolipid proteins, and residue proteins. J. Neurochem., 12, 205-211.

Lajtha, A. (1964). Protein metabolism of the nervous system. Int. Rev. Neurobiol., 8, 1.

Lees, M. B., Carr, S., and Folch, J. (1964). Purification of bovine brain white matter proteolipids by dialysis in organic solvents. Biochim. biophys. Acta. (Amst.), 84, 464-466.

Prensky, A. L., and Moser, H. G. (1966). Brain lipids, proteolipids and free amino acids in maple syrup urine disease. $J$. Neurochem., 13, 863-874.

Robinson, N. (1966a). Friedreich's ataxia: A histochemical study. Part 1. Enzymes of carbohydrate metabolism. Acta Neuropath. (Berl.), 6, 25-34.

-, (1966b). Friedreich's ataxia: A histochemical study. Part 2. Hydrolytic enzymes. Acta Neuropath. (Berl.), 6, 35-45.

-, (1966c). A histochemical study of motor neurone disease. Acta Neuropath. (Berl.), 7, 101-110.

$\longrightarrow$, and Williams, C. B. (1965). Amino acids in human brain. Clin. chim. Acta, 12, 311-317.

Rubinstein, L.J., and Smith, B. (1962). Triphosphopyridine nucleotide (TPN) diaphorase and TPN-dependent dehydrogenase activity of reactive macrophages in tissue necrosis. Nature (Lond.), 193, 895.

Soto, E. F., De Bohner, L. S., and Del Carmen Calviño, M. (1966). Chemical composition of myelin and other subcellular fractions isolated from bovine white matter. J. Neurochem., 13, 989-998.

Sperry, W. M., and Webb, M. (1950). A revision of the SchoenheimerSperry method for cholesterol determination. J. biol. Chem., 187, 97-106.

Spillane, J. D. (1962). Discussion on motor neurone disease: the clinical aspects. Proc. roy. Soc. Med., 55, 1019-1020.

Tallon, H. (1962). Amino Acid Pools, p. 471. Elsevier, Amsterdam. 